Max-Planck-Institut für demografische Forschung

Max Planck Institute for Demographic Research

Konrad-Zuse-Strasse 1 - D-18057 Rostock - GERMANY

Tel +49 (0) 3812081 - 0; Fax +49 (0) 3812081 - 202;

http://www.demogr.mpg.de

MPIDR WORKING PAPER WP 2012-017

APRIL 2012

\title{
Quantifying Patriarchy: \\ An Explorative Comparison of Two Joint Family Societies
}

Siegfried Gruber (gruber@demogr.mpg.de)

Mikołaj Szołtysek (szoltysek@demogr.mpg.de)

(C) Copyright is held by the authors.

Working papers of the Max Planck Institute for Demographic Research receive only limited review. Views or opinions expressed in working papers are attributable to the authors and do not necessarily reflect those of the Institute. 


\begin{abstract}
The notion of 'patriarchy' has pervaded the scholarly descriptions of peasant families in historical Eastern and South-Eastern Europe. The term has often included many different elements, such as the dominance of patrilineal descent, patrilocal or patrivirilocal residence after marriage, power relations that favour the domination of men over women and of the older generation over the younger generation, customary laws that sanctioned these patterns, the absence of an interfering state that could mitigate their influence, and an inert traditional society that emanated from these conditions. Combinations of these elements have been used to explain the peculiarity of the residence patterns in the East and South-East of Europe relative to the West, but in a manner that generally does not allow researchers to measure comparatively the 'intensity' of patriarchy across time and space. In this paper, we propose a handy tool for comparative studies of joint families, and argue that 'patriarchy' can be meaningfully measured in quantitative terms. We also suggest approaches for measuring patriarchy, and provide a list of numerical variables easily derived from census microdata that can be used for measurement purposes. To illustrate how these comparative studies can be conducted, we use census and census-like materials for two historical joint family societies from the European East (Poland-Lithuania and Albania). For both datasets, we compute a list of well-specified variables and investigate how they correlate with each other. Finally, based on these variables, an index of patriarchy is proposed, allowing us to identify regions with different degrees of patriarchy within one country.
\end{abstract}

\title{
1. Introduction: patriarchy
}

The joint family has long been seen as one of the most peculiar living arrangements in historic Europe. Despite the lack of clear terminological clarification (Madan 1962), the term 'joint family' (or extended family) has often been used to describe the laterally extended multiplefamily domestic groups found in societies widely dispersed across historic Eurasia, from nomadic tribes of the Middle East, to Slavic serf agriculturalists, to ancient civilisations of the Far East (Le Play 1982/1872: 259; Le Play 1871, § 12, p. 94; Devas 1886).

The term has been widely deployed in the description of peasant families from historical Eastern and South-Eastern Europe, as it has generally been assumed that these regions were dominated by unusually large and complex households. Some scholars have attributed this peculiarity in domestic group organisation to underlying cultural differences, arguing that Eastern European populations were more 'collectivist' than other European societies. An East-West polarisation of family patterns in Europe has been a cornerstone of a more general set of ideas, in which the assumed peculiarity of the Eastern European family system was linked to a high-pressure demographic environment characterised by excessive fertility and high mortality, poverty, the persistence of anti-modern values, social inequalities (including constraints on female autonomy), and other obstacles to the penetration of capitalism and its individualistic values (Macfarlane, 1978; Melegh, 2002). 
It is in this context that the concept of patriarchy has often been evoked in the analysis of family and kinship in Eastern and South-Eastern Europe, becoming a convenient shorthand for the presumed distinguishing trait of family relations on this part of the continent. However, in several important respects, the usage of the term in the context of historical studies of family in Eastern Europe has moved beyond its more conventional meaning-i.e., 'the rule of the father' - and has come to describe a system of social relations among the European peasantry that did not start to weaken until the family surrendered its productive functions sometime in the $19^{\text {th }}$ century (Mitterauer and Sieder 1982). This broader understanding of patriarchy went beyond the generational element, in which men dominated other family members based on the seniority principle (more on definitional issues in Walby 1989). As Kaser put it: "[I]t is insufficient to understand patriarchy simply as the rule of the father, the eldest, or the husband. We have to look also at the formalised rules that carry a patriarchal concept: inheritance rules, child obedience, marriage arrangements, residence at marriage, the presence or absence of institutionalised sexual assytery such as polygyny and different adultery rules, or the obedience of women" (Kaser 2008, 33; also Therborn 2004, 13).

This perspective is most clearly seen in the contemporary usages of 'patriarchy' in studies of historical family and kinship forms in the European East. The term often included many different elements, such as the dominance of patrilineal descent, patrilocal or patrivirilocal residence after marriage, power relations that favour the domination of men over women and of the older generation over the younger generation, customary laws that sanctioned these patterns, the absence of an interfering state that could mitigate their influence, and an inert traditional society that emanated from these conditions (Erlich 1966: 32; Halpern, Kaser, and Wagner 1996; Kaser 1992; Kaser 1996; Mitterauer 1999;).

However, even the most wide-ranging descriptions of Eastern and South-Eastern European 'patriarchy' (e.g., Kaser 2001, 2002, 2008; Halpern, Kaser, and Wagner 1996; Mitterauer 1999; for Russia, see Worobec 1995, 175-216) are not very useful when the task is to measure and compare the 'intensity' of patriarchy across time and space among historical societies, especially when the only available evidence is in the form of registers listing all individuals by their residential groupings. There are two reasons why measuring and comparing degrees of patriarchy may be useful. In our earlier study (Szołtysek and Gruber 2011), we showed that joint family societies with seemingly similar underlying concepts of kinship and descent may display significant differences in their household recruitment and domestic group organisational strategies, as well as in the life course patterns of individual 
members. We therefore recommended that researchers make a more conscious effort to systematise varying degrees of 'jointness' and 'apartness' across different complex family societies. This can now be done more effectively, as continuous improvements in census microdata revolution have made it feasible to assemble for the first time a very large amount of comparable individual-level data for continental Europe in pre-industrial times (see www.censusmosaic.org).

In this paper, we propose a handy tool for conducting comparative studies of joint families, and argue that patriarchy can be meaningfully measured in quantitative terms. We also suggest approaches for measuring patriarchy using census microdata, and provide a list of numerical variables that can be used for this purpose. Our list of indicators of patriarchy consists of the following variables: the gender of household heads, the kin composition of the households, sex ratio, age heaping, missing information about women, age at marriage, and household complexity. To illustrate how these variables can be employed in comparative analyses, we use census and census-like materials for two historical joint family societies from the European East (Poland-Lithuania and Albania). For both datasets, we compute a list of well-specified variables, and check how they correlate with each other. Finally, based on these variables, an index of patriarchy is proposed as a summary indicator of patriarchal structures, allowing us to identify regions with different degrees of patriarchy within one country.

Our own take on the issue is based on earlier works of several other scholars. M. Cain used the median age difference between once-married spouses as an indicator of patriarchal structure in a cross-national analysis of fertility in the developing world (Cain 1988; also Cain, Khanam and Nahar 1979). Cain rightly asserted that the age difference between spouses has several attractive features that make it a potentially useful indicator of patriarchal structure in a comparative demographic analysis (Cain 1988, 25-27). However, he seemed to fail to take into account some other demographic and domestic group characteristics that are no less essential to the demographic and familial development of peasant societies governed by the patriarchal rules defined above.

V. Erlich used quantitative methods to investigate changes in household structure in Yugoslavia during the 1930s. She used the term 'patriarchal regime' to describe a complex set of traditional ways of living and customs with deep roots in the distant past. At the centre of this regime was "the extended family, called zadruga" (Erlich 1966: 32). She calculated percentages of villages for the period of break-up of these kinds of households by regions (Erlich 1966: 46). 
An attempt to approach quantitatively the critical structural features of patriarchy was also present in the work of Halpern, Kaser, and Wagner (1996). The authors focused on the father-son and brother-brother dyads, and measured both the frequency of these relationships and their time span. Among the measures proposed were the age at marriage, the age at childbirth, and the sex of the last child (Halpern, Kaser, and Wagner 1996: 430-433).

Some of the measures mentioned above will be applied in our analysis as well, while others cannot be calculated using our data. Certain measures, like the numbers of father-son and brother-brother dyads, are greatly affected by the age structure and fertility of the population in question, and are therefore not used here. All in all, in its preliminary form, the methodological component of this paper indicates that some important extensions of those earlier efforts to systematise patriarchal structures at the societal level are needed. By making extensive use of historical population listings, this contribution seeks to foster further elaboration of the elements of patriarchal structure in different settings, and to clarify some outstanding issues related to typologisation of family systems across Europe. We will not, however, attempt to identify the economic or cultural factors that could explain the different levels of patriarchy observed.

\section{Data and settings}

To investigate the numerical dimensions of patriarchy, we used historical census microdata from two different regions of Eastern Europe: the eastern borderlands of the PolishLithuanian Commonwealth at the end of the $18^{\text {th }}$ century (today this area spans the countries of Poland, Belarus, and Ukraine) and Albania in 1918. The Albanian population census of 1918 and the Polish-Lithuanian database are the only existing databases that are large enough to allow for an investigation of demographic conditions and household composition in historical Eastern and South-Eastern Europe that is not subject to place-specific random distortions due to small numbers of observations.

On the Polish side, the present study makes use of data for 13,885 peasant households from eastern territories of historical Poland-Lithuania. This database, which is a part of a larger data depot known as the CEURFAMFORM Database (Szołtysek 2011) ${ }^{1}$, contains entries for 143 parishes or estates with 511 settlements and a total population of 83,727 (Table 1). These data were derived from two types of population listings enumerating individuals by residential units. The kinship relationships, household positions, and other demographic

\footnotetext{
${ }^{1}$ Various parts of this data collection have already been analysed (e.g., Szołtysek 2008a, 2008b; Szołtysek and Zuber 2009).
} 
information (age, sex, marital status) for each individual within the domestic group are provided $^{2}$. The first group of listings (37 per cent) comes from the surviving remnants of the censuses ordered by the Polish Diet (Sejm) in 1789, which were conducted for each of the territorial units of the Polish-Lithuanian Commonwealth between 1790 and 1791. The task of population enumeration was performed by local priests, and financial penalties were imposed on vicars who failed to fulfil their population registry duties. The second group of census microdata for the Commonwealth comes from Russian 'soul revisions'. Designed as periodic tax censuses to be used by the central government to assess the poll tax which all male peasants in Russia were liable to pay, these 'revisions' were first carried out in 1782 on the eastern outskirts of the Polish-Lithuanian Commonwealth, after the annexation of these territories a decade earlier by Russia ( $4^{\text {th }}$ Revision). However, the first comprehensive survey covering the Belarusian heartland of the Grand Duchy of Lithuania was not conducted until 1795, after the second partition of Poland ( $5^{\text {th }}$ Revision). Despite being ordered by the foreign administrators of the Polish territories, the 1795 revision in Poland-Lithuania was conducted in accordance with traditional Polish concepts of census-taking, rather than with the official Russian principles of taxation. Thus, local civil authorities and officials of Polish origin were primarily responsible for preparing and carrying out the enumeration.

The territories enumerated in the listings mentioned above cover the eastern fringes of the Polish-Lithuanian Commonwealth. Using the Polish borders just before 1772 as a reference point, the 143 parishes are clustered in four territorial groupings located on both sides of the historical Polish-Lithuanian border of the Commonwealth (Map 1). To the north of this border, two regions stretch over central and southern parts of the Grand Duchy of Lithuania (Regions 1 and 2). Region 2 has one of the largest swamplands in Europe, Poles'ya. To the southwest, Region 3 includes part of the historic territory of Red Ruthenia, which today lies at the intersection of Belarus, Ukraine, and Poland. Region 4 includes the Zytomierski district in the former Kiev Voivodship in the south-eastern fringes of the Commonwealth, which is sometimes attributed to historical Volhynia, and is now in Ukraine. Because these regions are based on the administrative grouping of parishes at the time the census was taken, they generally have a high degree of administrative coherence at their reference time point. However, for socioeconomic, demographic, and cultural reasons, the four regions are treated together for the purposes of this study. All of the listings discussed

\footnotetext{
2 The database development was supported by the Marie Curie Intra-European Fellowship Project (FP6-2002Mobility-5, Proposal No. 515065) at the Cambridge Group for the History of Population and Social Structure, Cambridge, UK, 2006-2008. More details in Szołtysek 2008a, 2008b.
} 
here precede the abolition of serfdom in the territories in question. The serf population under consideration was essentially non-Polish and non-Catholic, and was dominated by Uniates (Greco-Catholics), who mainly belonged to an ethnic group known as the Ruthenians (and who spoke different dialects: 'proto-Ukrainian' and 'proto-Belarusian'3 ${ }^{3}$, with only very minor Polish and Lithuanian influences. In addition, all of the regions under consideration had low population density, and less stringent forms of manorial economy based on the forced labour of the peasantry than those found in the western and southern-most territories of Poland-Lithuania.

The Albanian data come from the population census conducted by the AustroHungarian army in 1918 in Albania (Kaser, Gruber, Kera, Pandelejmoni 2011; for an evaluation see Nicholson 1999). The Austro-Hungarian army occupied the majority of the territory of the newly created independent Albanian state, and established a new administration in 1916. Officers of the Austro-Hungarian army collected the data with the assistance of Albanian officers (Seiner 1922: 3). The census personnel were male, and the individuals responsible for providing information about the members of each household were the (overwhelmingly male) household heads. However, the census-takers were instructed to make sure that no individuals, such as female children, were excluded from the count (Seiner 1922: 4). These efforts appear to have been successful, as the census counted almost the same number of men and women, whereas in censuses of other countries in the region, there was always a distinct male majority in the population (for Serbia, see Sundhaussen 1989: 80). This Albanian census is the first for which the original data are still available at the level of the individuals recorded, and it is of high quality given the circumstances under which it was taken (Gruber 2007: 257). As this census is still generally unknown, a demographic atlas of Albania cited data from 1926 as the earliest population data available (Bërxholi 2003). Gjonça mentioned only the preliminary census of 1916, and stated that the first general census conducted in Albania was in 1923 (Gjonça 2001: 38f.).

The research project, "The 1918 Albanian Population Census: Data Entry and Basic Analyses", based at the University of Graz and funded by the Austrian Science Fund (20002003), sought to convert the data into machine-readable form. ${ }^{4}$ The data remain at the individual level, which allows for much more detailed research than aggregate data at the village level. The researcher is able to aggregate data as s/he wishes, and is not bound to the

\footnotetext{
${ }^{3}$ Not to be confused with Carpatho-Russians or Rusnaks from the Sub-Carpathian areas in Eastern-Central Europe.

${ }^{4}$ http://www-gewi.uni-graz.at/suedost/seiner/index.html
} 
categories of previously aggregated data (Hall, McCaa, and Thorvaldsen 2000: 9). This also enables the researcher to combine different variables on the individual level for research purposes. The census data of 1918 are a rich source for a variety of questions related to studies about population structure and behaviour. Because the age, birth place, and the place of residence were registered for each person, data for marriage patterns are available. Up to now, the data of 309 villages and cities have been entered in a database, which contains 140,611 persons. The database contains a 10-per cent sample of villages covering the whole of the area of surviving census data, and a 100-per cent sample of settlements of special interest (including all cities). The data of the 10-per cent-sample are weighted to account for the population size of administrative units according to the published results (Seiner 1922). These data have already been used for analyses of household structures, ages at marriage, fertility, and migration (Gruber 2005, 2008, 2009, 2010, 2011; Gruber and Szołtysek 2012; Kera and Pandelejmoni 2008).

More than two-thirds of Albania is mountainous, especially in the north. Most of the western border is formed by the Adriatic Sea, and there are plains along the coast. Durrës is a port city, Shkodra is situated on a large lake, Kavaja is not far from the coast, and the other three cities in this study are located in the interior of the country. Shkodra is the only city in northern Albania, while the other five cities are located in central Albania; the cities of southern Albania lie outside the territory of this census. The majority of the population was Muslim (78.2 per cent), and only the prefecture of Puka was predominantly Catholic. The only city with a sizable Catholic population was Shkodra (making up about one-third of the population). The Orthodox population in this study is mainly urban because the major areas inhabited by Orthodox Christians are either outside of the area covered by this census, or are areas where the census originals have not been preserved.

The analysis was done by comparing different regions of the area of the Albanian census of 1918. This area was divided into seven prefectures at that time, and the six cities of this area are separated from the prefectures, as it can be assumed that the urban population had different behavioural patterns than the rural population. The sub-prefecture of Gora has been separated from the prefecture of Zhuri, because this region was known for its large number of male migrant workers, which makes it distinct from the neighbouring regions. The analysis is therefore based on 18 areas: eight rural Albanian regions, six Albanian cities, and four regions in the eastern part of the Polish-Lithuanian Commonwealth. 
Table 1: Data used

\begin{tabular}{|l|r|r|}
\hline Region & N unweighted & N weighted \\
\hline Kruja & 4,276 & 47,897 \\
\hline Puka & 5,008 & 32,506 \\
\hline Shkodra & 12,340 & 60,915 \\
\hline Tirana North & 14,529 & 80,004 \\
\hline Zhuri & 15,565 & 85,616 \\
\hline Gora & 11,298 & 14,933 \\
\hline Tirana South & 12,206 & 31,586 \\
\hline Berati & 7,424 & 24,409 \\
\hline Kruja (city) & 3,893 & 3,893 \\
\hline Shkodra (city) & 23,590 & 23,590 \\
\hline Durrësi (city) & 4,307 & 4,307 \\
\hline Elbasani (city) & 10,237 & 10,237 \\
\hline Kavaja (city) & 5,522 & 5,522 \\
\hline Tirana (city) & 10,416 & 10,416 \\
\hline Albania overall & $\mathbf{1 4 0 , 6 1 1}$ & $\mathbf{4 3 5 , 8 3 2}$ \\
\hline Region 1 & 19,176 & 19,176 \\
\hline Region 2 & 25,332 & 25,332 \\
\hline Region 3 & 25,193 & 25,193 \\
\hline Region 4 & 14,026 & 14,026 \\
\hline $\begin{array}{l}\text { CEURFAMFORM east } \\
\text { overall }\end{array}$ & $\mathbf{8 3 , 7 2 7}$ & $\mathbf{8 3 , 7 2 7}$ \\
\hline & & \\
\hline
\end{tabular}

The populations covered by our listings represented joint family societies per se, with a large share of individuals living in joint family constellations at some point in their life course. In a previous comparative analysis of living arrangements of the aged by the same authors, data from the Polish borderlands and Albania displayed some of the highest indicators of joint family co-residence out of more than a hundred census populations from around the globe (Gruber and Szołtysek 2012). Further evidence of the prevalence of jointfamily co-residence in the areas under scrutiny come from ethnographic accounts and historic-anthropological research. According to Kaser, Albania historically belonged to the area of the Balkans where patrilocal-household cycle complexity was prevalent (Kaser 1996, 383; Gruber 2012). In the patrilocal residence pattern, the wife moved into the household of her husband, who lived with his father and with his brothers even after the father's death. The male offspring constituted the nucleus of the household, while female offspring had to leave the household at the time of marriage. The transmission of property was not related to death or marriage and took place after generations, when the household divided into several different groups. In particular, the area covered by Albania was characterised by a distinctive 
patriarchal cultural background that has been called Balkan patriarchy (Kaser 1995, 61-165). The basic elements of this cultural pattern were strong blood ties, ancestor worship, patrilocality, patrilineal kinship structures, bride price, and blood feuds (Kaser 2008).

One study defined Balkan patriarchy as a complex of hierarchal values embedded in a social structural system defined by both gender and age: "This structuring is further linked to a system of values orienting both family life and broader social units. Balkan patriarchy achieves its historical form through the classically complex and interlocking systems of patrilinearity, patrilocality, and a patriarchally-oriented common law. Such supports not only divide and ascribe position by gender, but also allocate to males the predominant role in society. An obvious corollary to this defined structure is the formal subordination of women within the context of an overtly 'protective' family and household environment" (Halpern, Kaser, and Wagner 1996: 427). The male moral authority was reinforced by both traditional and state law (Hasluck 1954; Kanuni 1989; Whitaker 1976; Whitaker 1981). In addition, the patriarchal system in Eastern and South-Eastern Europe was connected to a system of equal male inheritance, and Albania fitted into this pattern (Kaser 2000, 2002).

There was also an important religious aspect in this patriarchal culture: the veneration of a patron saint of the family was the most important religious feast of the year. The festivities were held at home and not in a church, which is an important factor in placing the focus on lineage identity. The pre-Christian worship of ancestors of the patrilineage was substituted by a Christian patron saint (Kaser 1993: 93-122).

There were differences in levels of patriarchy in Europe around 1900: moving further to the south and east of the continent, the patriarchal rules became progressively more rigid (Therborn 2004: 71). Northern Albania was seen as the most patriarchal region within Albania, a country that was generally considered to be very patriarchal around 1900 . The regions were inhabited by "extremely patriarchal groups" (Fischer 1999: 281), living in a "fully fledged tribal society in the middle of Europe" (Backer 2003: 59), and practicing blood feuds and the tradition of "sworn virgins" (Young 2000; Boehm 1984).

The eastern lands of historical Poland represented a similarly peculiar cultural landscape characterised by the longevity of archaic forms of communal social organisation based on male ancestral kinship. Throughout late medieval and early modern times, a special form of peasant landowning pattern known as 'Syabrinstvo' or 'Dvorisha', based on common ownership of land, joint production activities, and the close residential proximity of related family units, was widespread among Ukrainians and Belarusians. It was assumed that this arrangement recalled the image of the extended family as a kind of property and labour 
cooperative. These familial-ancestral communes closely resembled the well-known southern Slavic institution of zadruga (Kovalevskii 1885, 36-37, 54-55; Leontovich 1896; Efimenko 1892; Kosven 1963, 168-169; Gimbutas 1971, 133; Lutchitsky 1896[1889]; also Balzer 1899; Łowmiański 1967, 344-372). In those areas in early modern times, there were a number of villages comprised exclusively of a community of people bound by patrimonial unity and occupying lands retrieved from forests by the collective effort of ancestors (and who sometimes, but not always, resided on collective premises). These communes would have one head/chief, with the members including not only fathers, sons, brothers, and nephews; but also cousins and grandfathers. The patriarchal model of intra-familial relations prevailed. Full economic power was held by the commune's superior (usually the oldest male), and this power was passed to the next-oldest male in the group after his death (Downar-Zapoloskij 1909[1897], 9-12). The introduction in the mid-16th century of the manorial system, in which peasant labourers were organised by separate hearths, led to the gradual dissolution of old forms of social-territorial and familial organisation based on ancestral kinship (Szołtysek and Zuber-Goldstein 2009), but was never fully successful (Efimenko 1892, 377, 393-394; Balzer, 1899, 193-199; Łowmiański, 1967, 346-362) ${ }^{5}$. In the period under investigation, large agnatic descent groups were already at different stages of disintegration, mainly because landlords were making active efforts to break up large families, and were encouraging the creation of individual families (Szołtysek 2008a). Archaic patterns of extended family continued to be widespread in the Polish eastern borderlands, although by that time the patriarchal family group was primarily confined to individuals who jointly inhabited one domestic group ('dym'). Despite the efforts made to divide households, large multi-generational families had not yet disappeared from the Polish eastern territories by the second half of the $19^{\text {th }}$ century (Downar-Zapoloskij 1909[1897]).

The only thorough accounts of the patriarchal structures in the Polish eastern territories can be found in a late $19^{\text {th }}$-century ethnographic description by Dovnar-Zapolskij (Dovnar-Zapolskij 1909) of the Poleshuk population in the swamp area of southern Belarus (Region 2 on Map 1), and in a 1930s study by a student of Malinowski, J. Obrębski (Obrębski 2007). Although Obrębski's field notes from the 1930s were rather place-specific, it could be argued that the patriarchal features they described for the linguistically defined area of

\footnotetext{
${ }^{5}$ Efimenko attributed the persistence of ' $d$ vorishe' forms in the Ukraine in the second half of $17^{\text {th }}$ century to the durability of traditional mental constructs. According to her, the population, who had followed communal traditions for many centuries, had not yet completely adapted to the rules of individualised property (Efimenko 1892, 400-401).
} 
Polessia were only extreme manifestations of similar trends already occurring in other Belarusian and northern Ukrainian territories represented in the database.

Obrębski stressed the highly patrilineal orientation of the Polessian rural folk. However, this feature encompassed more than just the mere dominance of male inheritance and patrilocal marriage: it was about the centrality of the relationship between the fathers, the sons, and the land they all cultivated (Obrębski 2007, 145). Land was perceived as central to the very organisation of the economic and domestic life of Poleshuks. The land-family bonds that were typical of many rural societies in pre-industrial times were far stronger in this culture, as land was seen not as just the property of a particular householding family, but rather as the possession of the patrlineage. At the centre of the grand-familial organisation in Polessia was a concept that Obrębski called 'patrolatria': a god-like sanctity attributed to the father. This cult of the father-truly an essential feature of family relations in this areagenerally also translated into a widely accepted notion of the exceptionality and superiority of the social status of the elderly (Obrębski 2007, 150-151). In all of the family types in the part of Belarus investigated by Dovnar in the late $19^{\text {th }}$ century, full economic power was held by the commune's superior (choziain). This was usually the oldest male of the commune, and his position corresponded to the status of leaders of grand families among Great Russians, or of heads of Serbian zadrugas. If a given family commune did not split after the demise of the head, the power over the collective was generally passed to one of its oldest male members, although there were also cases of widows managing the household (Downar-Zapoloskij 1909[1897], 9-12). The progressive individualisation of family life meant that the situation of seniors had to be decisively secured. Usually, the departing household head retained the right to part of the property, which he would often cede to the child (normally the youngest son) who was obliged to provide him and his wife with lifelong board (Downar-Zapoloskij 1909[1897], 15). Big family communes of brothers (siemejnye obschiny), sometimes consisting of as many as 15-25 inhabitants, were found in the Polessian district of Pińsk as late as in the 1890s. These communes sometimes lasted the entire lifespans of the brothers or even longer, which led to the emergence of more or less durable co-resident domestic groups of uncle and aunt with nephews. In some parts of Belarus (Boruyskie; a section of Region 2 in Map 1), the creation of artificial joint families accompanied the disappearance of historical residential ancestral communes.

There were other important features of Polessian patriarchal organisation, such as strict patriarchal family relations. These features were closely associated with the cultural inclinations of these eastern populations. The scarce ethnographic evidence available for later 
periods indicates that recourse to hired work (i.e., workers who did not belong to the family collective of relatives) was minimised to the greatest extent possible, or was avoided altogether. Various other aspects of the prevailing mentality could be mentioned in this context, including the notion of female honour: i.e., considerable value was placed on the protection of female virginity prior to marriage by male members of the household and kin, which led to the general view that, for young women, being in service meant disgrace, and even humiliation.

The ethnographer J. Witort (Witort 1895) made similar observations for Lithuania, (including some of the regions lying to the north in Region 2, Map 1). In the northern regions of the country bordering Kurland, he detected "family communes" usually made up of "the father's family and his wife, married sons and bachelors, married daughters and maidens, sons-in-law, grandsons, sometimes - but rarely - adopted persons", all living under one roof and jointly managing the household (Witort 1895, 2). Such residential communes were organised on the seniority principle, and their estate was not subject to alienation, unless all of the mature males gave their consent. Evidence was found that the duty of blood vengeance for agnates sporadically persisted among these families in the 19th century. The patriarchal model of intra-familial relations prevailed, even though all of the adult members of the commune had the right to leave, regardless of gender. Earlier, Lithuanian communes were characterised by substantial stability: they would usually last even after the death of the superior, and their eventual disintegration was the result of generally accepted divisions. Though once widespread in the regions of Lithuania proper, family communes were a thing of the past by the time Witwort conducted his study, giving way to small families composed of parents and children only (Witort 1895, 6-7).

\section{Measures used}

\subsection{Headship}

3.1.1 Proportion of female household heads (fhhh1; for all subsequent variables, see Table 2 at the end)

This variable is the proportion of all female household heads among all of the household heads of family households. We expected to find that this measure was negatively correlated with patriarchy, because we assumed that, in truly patriarchal areas, women would not have become household heads, unless no other option was available.

For the 18 regions studied, the mean proportion of female household heads was found to be 6.5 per cent, with a range of 1.8 to 14.0 per cent. Thus, the results indicated that very 
few women headed households. Most of the cities had much higher proportions of female household heads than the rest of the country. However, in the historical Polish east, the overall level of female headship was higher than in rural Albania and in rural areas of western Poland, where the nuclear family system prevailed (Szołtysek 2009, 456).

\subsubsection{Proportion of female household heads (fhhh2)}

In households made up of only male or female adults, it is not necessary to choose between a male or a female household head. Therefore, with our second variable, we measured the proportion of female household heads, restricting ourselves to households with at least one adult man and one adult woman ${ }^{6}$.

This measure should be negatively correlated with patriarchy. We assumed that, in truly patriarchal societies, women would not have led the household if there was an adult male in the household, unless there was no other option available ${ }^{7}$.

For the 18 regions studied, the mean percentage of female household heads in households that included an adult male was found to be 1.7 per cent, with a range of 0.0 to 7.3 per cent. Not surprisingly, the analysis showed that were even fewer women heading households in cases in which there was an adult man who could act in that capacity. However, the patterns observed in Belarus and Ukraine stand out very clearly from the rest of the sample. Higher levels of female headship were reported for these regions than in both rural and urban Albania. Surprisingly, this also holds true for the Polessian region: the PolishLithuanian data indicated that this region was characterised by extremely complex and partilocally formed households.

\subsubsection{Proportion of underage male household heads (mhhh1)}

Another way of excluding women from headship is to install male children as household heads. Therefore, the next variable measured the proportion of underage male household heads of households in which the only males were under 10 years of age, and in which there was at least one adult woman ${ }^{8}$. We expected this measure to be positively correlated with patriarchy, based on the assumption that, in truly patriarchal areas, women would not have become household heads if boys were present.

\footnotetext{
${ }^{6}$ Another condition was that the household head must have been present at the time of the census. In this context, 'adult' was defined as a person who was at least 18 years of age or who had been married. The second definition was added to include people with missing ages, but who were obviously adults.

${ }^{7}$ It should be noted, however, that disabilities were not treated as factors excluding adult men in this measure.

${ }^{8}$ All of these persons (including the household head) had to have been present at the time of the census, and only family households were considered.
} 
For the 18 regions studied, the mean share of such cases was found to be 49.6 per cent, with a range of zero to 100 per cent. The wide range of results was caused by low numbers in some cases. Certain features stand out very clearly. In many regions of Albania, appointing a very young boy as household head was obviously seen as a desirable solution, even if the household was actually led or supervised by the boy's mother. The patterns observed in eastern Poland-Lithuania were very different. In two regions of the Polish east, no arrangement of this kind can be found in the 18th-century material, while in the other two regions, the numbers of such cases appear to have been negligible.

\subsubsection{Proportion of male household heads who were not the oldest man in the household (mhhh2)}

The hierarchy of age was expected to be the prime principle structuring the relationships between household members in patriarchal societies (Kaser 2008, 33). Although under strict patriarchal rules the oldest man should act as household head, our material showed that there were households in which younger men held this position.

This variable measures the prevalence of this tendency across the 18 regions. It is restricted to households with at least two adult men of known age who were present in the family household at the time of the census-taking. The household head must have been present at the time of the census. We posited that, the more patriarchal the rules of household formation were, the less likely it was that a younger household member would assume leadership of the residence group.

As we can see in Table 3, in the overwhelming majority of cases under consideration, the oldest man was the head of household, and the share of households in which a younger man assumed leadership was small in most regions. For the 18 regions studied, the mean share of such cases was 11.9 per cent, with a range of 4.0 to 22.7 per cent. However, the seniority principle was not an absolute rule in any of the regions studied. The rural Albanian regions had the highest percentage of households headed by a younger male, and the share was also relatively high in 18th-century Ukraine. In both the Albanian and the PolishLithuania rural samples, a north-south division appears to have been present. Male headship seems to have been structured according to the seniority principle to a greater degree among the Belarusians than among the Ukrainians in the 18th-century Poland, and to a greater extent among the northern Albanians than among the southern Albanians. Out of all of the rural regions included, the proportion of households headed by a younger male member was found to be the lowest in Polessian part of Belarus (Region 2). 


\subsection{Composition of the household}

\subsubsection{Proportion of relatives in the household on the wife's side}

From the principle of patrilineality, it follows that only relatives of the husband should be present in a household headed by a 'patriarch'. Thus, with the following variable, we measured the share of relatives from the wife's side among all of the relatives in present in the household who can be assigned either to the husband or wife, and who were present at the time of the census. The following persons were excluded from this analysis of family households: household head, spouses, common relatives (children and other descendants), relatives of either the head or the spouse, unrelated persons, and persons with an unknown relationship to the household head. This measure should be negatively correlated with patriarchy, as it is assumed that, in truly patriarchal societies, the right to household membership would normally have been restricted to agnatic kin of the head.

For the 18 regions studied, the mean proportion of relatives in the household on the wife's side was 4.5 per cent, with a range of 0.6 to 11.7 per cent. We can see that only a few relatives of the wife were included in households in the two areas under investigation. The overwhelmingly low percentages of relatives from the wife's side of the family should not obscure important differences between regions. By far the lowest proportions were recorded in Albanian rural regions, while in the urban regions of the country, the shares were much higher. Rural communities in the Polish east also diverged sharply from the Albanian pattern, having on average four times more household members related to the wife. The region with the most complex family arrangements in Poland (Region 2) was also found to have had the lowest share of co-residents related to the wife.

\subsection{Higher mortality of women}

\subsubsection{Sex ratio}

Based on the premise that women are generally treated worse than men in patriarchal societies, we expected to find higher levels of female than male mortality. The measure used to test this assumption was the sex ratio of all of the persons present at the time of the census. We could not, however, determine whether there were fewer females recorded in the census because women had higher levels of mortality, or because women were under-registered, as both are likely outcomes of a patriarchal regime. We assumed that this measure would be positively correlated with patriarchy, because increasing degrees of patriarchy would have led to higher levels of female mortality or female under-registration. 
For the 18 regions studied, the mean sex ratio of mortality was 98.2, with a range of 74.8 to 108.6 . The sex ratio was actually quite balanced on average, but most of the regions had a clear male or female surplus. Three out of four regions of the CEURFAMFORM database had a male surplus, while most of the Albanian regions had a female surplus. The extreme case of Gora is attributable to the high share of men working as seasonal migrants.

\subsection{Age awareness and quantitative literacy}

\subsubsection{Ratio of female to male age heaping}

We have chosen to treat the degree of digit preference or avoidance (a problem commonly known to demographers as age heaping) as a proxy for what has been increasingly called 'quantitative literacy' (see A'Hearn, Crayen, and J. Baten 2009, and Baten and Szołtysek 2012). It has been widely assumed that men had higher levels of quantitative literacy (and hence a higher level of human capital) than women in many traditional societies, as patriarchal societies with pronounced gender inequalities would have also had greater educational inequalities. These educational gaps would have led the generally male household heads to misreport the ages of female household members. The measure we used is the ratio of Whipple's indices comparing women and men. Only the individuals who were present at the time of census were considered. This measure should have been positively correlated with patriarchy: the stronger the 'patriarchal bias', the greater the discrepancy between male and female age reporting patterns, and the higher the index value.

For the 18 regions studied, the mean ratio of female to male age heaping was found to be 131 per cent, with a range of 87 to 173 per cent. These results clearly showed that there were much greater levels of inaccuracy in the reporting of female ages relative to male ages in all of the Albanian regions. However, the opposite trend was observed in the Belarusian and Ukrainian regions. There, in three out of four regions, the quality of age reporting was clearly higher for females than for males. Despite a strong tendency among these societies towards patrilocal joint family organisation, the misreporting of ages seems to have been less of a problem among women than among men.

\subsubsection{Ratio of females to males proportions of people with unknown age}

This measure is the ratio of the proportion of female household members with unknown ages to the proportion of male household members with unknown ages. We expected to find that this measure was positively correlated with patriarchy, because we assumed that increasing 
degrees of patriarchy would have led to increasing levels of ignorance among generally male household heads of the ages of female household members.

For the 18 regions studied, the mean ratio of female to male proportions of people whose age was unknown was found to be 144 per cent, with a range of zero to 632 per cent. Because most of the regions had only a few cases, this measure is not very helpful.

\subsection{Age at marriage}

\subsubsection{Lower age at marriage for women}

This measure is the singulate mean age at marriage for women. We expected to find that this measure was negatively correlated with patriarchy. We assumed that increasing levels of patriarchy would have led to lower ages at marriage for women, because lower ages among brides tends to reinforce male domination of the household (De Moor and Van Zanden 2010).

For the 18 regions studied, the singulate mean age at marriage for women was 18.8 , with a range of 16.7 to 20.8 years. The singulate mean ages at marriage for women were generally low, and below the threshold of 21 suggested by Hajnal for joint household systems (Hajnal 1982: 452), even in the Albanian cities. The Polessian region from the PolishLithuanian sample, along with Kruja region of Albania, represent two extreme cases of very low female age at marriage.

\subsubsection{Larger age gap between spouses}

This variable captures the difference between the male and female singulate mean age at marriage.

The age gap between spouses has garnered significant attention among demographers and family historians alike (e.g., Cain 1988; Casterline et.al. 1986; Smith 1973). Whereas a relatively small age difference is one of the distinguishing features of the Western European family system (Laslett 1977), in societies in which social and economic relations are structured by patrilineage, the average age differences between spouses are commonly assumed to be relatively large. Where the patrilocality is the rule-i.e., the bride joins the household of her husband's family upon marriage-wives who are younger than their husbands may be more easily moulded into the roles desired by the husband's family (Davis and Blake 1956; Casterline et.al. 1986). We assumed that this measure would have been positively correlated with patriarchy, because-all other things being equal—increasing patriarchy is generally associated with higher levels of gender inequality and male 
domination, which can best be fostered by maintaining large age differences between the spouses.

For the 18 regions studied, the mean age difference between spouses was 7.6 years, with a range of 3.0 to 13.9 years. The largest age gaps were found in the Albanian cities, in which brides were, on average, 10 years younger than their husbands. The differences were only slightly smaller in the Albanian countryside. On the other hand, all of the regions with small age gaps were located in the eastern regions of Poland-Lithuania. In those areas, the age differences between spouses were half as large or smaller than in Albania. The contrasts between the joint family societies considered here are particularly intriguing, and we shall come back to this problem in the concluding paragraphs.

\subsection{Higher complexity of households}

\subsubsection{Proportion of people living in multiple family households}

Like early marriage, the large multi-generational and patrilineally structured family households have long been thought to be characteristic of patriarchal family relations (e.g., Czap 1983; Warpula 2002). Therefore, our next variable measures the proportion of people living in multiple family households, based on the Hammel-Laslett typology (Hammel and Laslett 1974). We expected to find that this measure was positively correlated with patriarchy, because we assumed that increasing patriarchy would lead to a higher degree of complexity of households.

For the 18 regions studied, the mean proportion of people living in complex households was found to be 44.4 per cent, with a range of 21.5 to 67.5 per cent. A clear regional pattern again emerged. In most of the rural regions of Albania, at least half of the population were found to have lived in multiple family households; while the proportions were considerably lower in the cities, where they hardly exceeded one-third of the respective population. The picture was even more diverse in the Polish eastern areas. Whereas in the Polessian part of Belarus (Region 2), two-thirds of the population lived in fairly complex family arrangements; in the remaining regions, the proportions were significantly lower.

\subsubsection{Proportion of elderly people living with at least one married child}

An alternative measure for household complexity is the proportion of elderly people (aged 65+) living with at least one married child (Ruggles 2010). We expected to find that this measure was positively correlated with patriarchy. We assumed that the stronger the patriarchal control over the life course decisions of the domestic group members, the higher 
the probability that sons would have married into the family household and that daughters would have left the household upon their marriage, and the lower the risk of the group dividing into several independent residence units. All of these tendencies would have led to a higher degree of complexity of residential groups.

For the 18 regions studied, the mean proportion of elderly people with at least one married child was 58.5 per cent, with a range of 33.8 to 79.8 per cent. All of the regions of historical Poland had shares of elderly people living with at least one married child of close to 70 per cent or above, while the average share in the rural Albanian regions was 57 per cent, and the average share in the Albanian cities was 43 per cent. These proportions were generally higher than those of people living in multiple family households, except in the Albanian rural regions, where the proportions were almost the same.

\section{Correlation of measures}

Our next step consisted of checking whether all of these different measures were correlated with each other, and whether the direction of a particular relationship was in line with our theoretical assumptions. Our goal was to identify those variables that have the closest bivariate relationships, and in doing so to distinguish the measures that are best able to capture the patriarchal characteristics of the populations under consideration. Table 3 (at the end) presents the matrix for ecological correlations between 12 variables at the regional level. Out of these 12 measures, the values of two are questionable due to the small number of observations in in some of the regions (people with unknown age and underage male household heads). The measure of people with unknown age was not found to be significantly correlated with any other measure, and was therefore excluded. By contrast, the measure of underage male household heads was found to be significantly correlated with three other measures, with a correlation coefficient of at least 0.5 . This suggests that this measure fits well into the framework of these measures of patriarchy, despite being affected by low numbers of cases for some regions. The measure of whether the oldest man was always the household head was the second measure which was not shown to be significantly correlated with any other measure, and it will therefore be excluded from future analysis. The closest relationships among the remaining measures can be seen in Table 4. 
Table 4: Closest correlations between measures of patriarchy

\begin{tabular}{|l|l|l|}
\hline Measure 1 & Measure 2 & correlation coefficient \\
\hline 1. SMAM difference & elderly living with married child & $-0.82^{* *}$ \\
\hline $\begin{array}{l}\text { 2. per cent female household } \\
\text { heads2 }\end{array}$ & ratio of Whipple's indices & $-0.70^{* *}$ \\
\hline $\begin{array}{l}\text { 3. per cent female household } \\
\text { heads1 }\end{array}$ & per cent wife's relatives & $0.69^{* *}$ \\
\hline $\begin{array}{l}\text { 4. SMAM female } \\
\text { household } \\
\text { 5. sex ratio multiple family }\end{array}$ & $-0.65^{* *}$ \\
* Correlation is significant at the 0.01 level & \\
\hline Correlation is significant at the 0.05 level
\end{tabular}

The closest relationship was found between the variables 'SMAM difference' and 'elderly person living with at least one married child'. This correlation is negative, and the second variable is also significantly correlated with the variables 'living in multiple family household' (positively), 'Whipple's indices' (negatively), and fhhh2 (positively). Therefore, this variable was shown to have the highest number of significant correlations of a level of at least 0.5 with other variables. Generally, the variables listed in Tables 2 and 3 are positively or negatively correlated following the assumptions indicated above. The only exception found is the measure 'elderly people living with at least one married child', which is generally correlated in the opposite direction. This variable turns out to be a central component in the analysis of patriarchy, but the opposite direction of the correlation makes it necessary to reconsider the theoretical assumptions about the relationship of the variable with patriarchy.

The variable 'SMAM difference' was also shown to be significantly correlated with the variables 'Whipple's indices' (positively) and fhhh2 (negatively). The variable 'Whipple's indices' was found to be significantly correlated with fhhh2, which is the second-closest correlation of the variables in this analysis. In addition, the results indicated that it is significantly correlated with the variables 'SMAM difference' (positively), 'elderly person living with at least one married child' (negatively), and mhhl (positively). The variable fhhh2 is correlated significantly with the variables 'Whipple's indices', 'SMAM difference', mhhh1 (all negatively), and 'elderly person living with at least one married child' (positively). These four variables (plus mhhh1) therefore make up an initial group of variables which are all significantly correlated with each other.

A second group of four variables is made up of the pairs fhhh1 and 'per cent wife's relatives' (positively correlated) and 'SMAM female' and 'living in multiple family household' (negatively correlated). In this group, not all of variables are significantly correlated with each other: 'living in multiple family household' is significantly correlated 
with all three of the other variables of this group, fhhh1 and 'per cent wife's relatives' are significantly correlated with two other variables, while 'SMAM female' is significantly correlated with only one variable of this group.

The variable 'sex ratio' is the most separated of these nine variables. It is significantly correlated with only one variable ('SMAM female').

\section{Index of patriarchy}

In a final step, an index of patriarchy was created (Table 5). It was made up of the following six components:

- female household heads (the two measures are combined)

- relatives of the wife

- sex ratio

- ratio of Whipple's indices

- SMAM for women

- co-residence (living in multiple family households and elderly living with at least one married child are combined)

Each of the six components provide points of patriarchy for each region according to the results in Table 2, and the assumptions about the correlation between the respective variable and the degree of patriarchy (either starting from the highest or the lowest level):

- two points for the six regions with the highest levels of patriarchy,

- one point for the six regions with medium levels of patriarchy, and

- zero points for the six regions with the lowest levels of patriarchy.

The range for the regions in the analysis is, therefore, zero (always in the lowest category) to 12 points (always in the highest category).

The difference of the SMAM between men and women was excluded because there were obviously differences in the patterns between the two datasets used for this analysis. Coresidence was used in two ways: first, the variable 'elderly living with at least one married child' was used in the assumed correlation; and, second, it was used in the opposite way, as this seems more appropriate given the results of the correlation analysis of the other variables. 
Therefore, two sums for the index of patriarchy exist, but the second seems to be more appropriate.

Generally, the rural Albanian regions score highest in this index of patriarchy, especially those in northern Albania. The region of Gora had lower levels of patriarchy, and was closer to the rural regions of central Albania. Three cities (Tirana, Kavaja, and Kruja) had scores similar to those of the rural regions of central Albania, while the other three cities had low levels of patriarchy. The eastern regions of the Polish-Lithuanian Commonwealth had low patriarchy scores, with the exception of Region 2, which was found to have been similar to some of the rural regions of Albania. The aggregate gradation is very clear: the lowest level of patriarchy was in the Polish east, medium levels of patriarchy were found in Albanian cities, and the highest level of patriarchy was in the Albanian rural countryside.

The results confirm the general assumption that northern Albania was the most patriarchal region within Albania. Some of the Albanian cities had higher patriarchy scores than expected. This can be attributed to the influence of the rural hinterland, from which many urban residents originally came. This does not hold true for Shkodra, which was situated in northern Albania, but was also by far the largest city in this study. Both Shkodra and the port city of Durrës had very high literacy rates (Gruber 208: 143).

Poles'ya was found to differ from the eastern regions of the Polish-Lithuanian Commonwealth, which confirmed the ethnographic evidence cited at the beginning of this paper. The patterns detected for the remaining three regions of eastern Poland-Lithuania are quite striking, as they deviate significantly from many of the tendencies found to be present in the Balkan area. This diversity of patterns stemmed from the interplay of various socioeconomic, institutional, and ecological factors that are too complex to be fully discussed here (see, however, Szołtysek 2012). In short, we can observe that manorialism and interventions by landlords in the lives of peasant, combined with regional economic disparities, created a political economic framework within which historical tendencies to form corporate family groups must have been constrained and mitigated.

\section{Conclusions}

Our analysis shows that it is possible to construct variables for measuring patriarchy. A set of 12 variables were designed, and nine of them can be used. These variables generally correlate significantly with some of the other variables used for measuring patriarchy. The results generally confirm the ethnographic evidence regarding higher or lower degrees of patriarchy, but some of the results are not in line with expectations. The variable 'elderly person living 
with at least one married child' poses a slight problem, because its correlation with other variables measuring patriarchy does not follow the theoretical assumptions. This could be because this measure does not sufficiently capture patriarchy. This variable should perhaps be replaced by another that is better at measuring co-residence in patriarchal regions (Gruber and Szołtysek 2012) ${ }^{9}$. The discrepancies in the results between these two datasets point to another possible obstacle: these variables may be better suited for capturing patriarchy in Albania than for capturing patriarchy in the eastern parts of the Polish-Lithuanian Commonwealth. This could be checked with additional datasets.

We are well aware that the list of variables used for measuring patriarchy in this paper is only a first attempt at creating variables for such a purpose. Additional variables could be constructed, which might broaden the picture and capture other aspects of patriarchy, such as the proportion of adult children still living with their parents, the ratio of married sons to married daughters (or sons-in-law) in the household, or the proportion of polygamous men (applicable only in countries where polygamy was allowed). In addition, we have not yet dealt with the possible explanatory factors (economic or cultural) for the differing levels of patriarchy.

\footnotetext{
${ }^{9}$ Many elderly from the Polish east living with at least one married child were actually living with only one married child. Therefore, they represented a family environment that more closely resembled that of a 'classic' stem family than of a 'typical' joint family type of co-residence.
} 


\section{Bibliography}

A'Hearn, B., Crayen, D. and J. Baten (2009). Quantifying Quantitative Literacy: Age. Heaping and the History of Human Capital, Journal of Economic History 68

Baten, J.; Szoltysek, M.(2012). The human capital of Central-Eastern and Eastern Europe in European perspective. Rostock, MPIDR Working Paper WP-2012-002.

Berit Backer (2003) Behind Stone Walls: Changing Household Organization among the Albanians of Kosova. Peja.

Arqile Bërxholi, ed. (2003) Atlasi gjeografik i popullsisë së Shqipërisë: Atlasi i Shqipërisë = Demographic Atlas of Albania. Tiranë.

Christopher Boehm (1984) Blood Revenge. The Anthropology of Feuding in Montenegro and Other Tribal Societies. Lawrence.

Cain, M. , S. R. Khanan, and S. Nahar. 1979. "Class, Patriarchy, and Women's Workin Bangladesh." Population and Development Review 5:408-16.

Cain, M. (1988). Patriarchal structure and demographic change. In: Conference on Women's Position and Demographic Change in the Course of Development (1988: Oslo). Solicited papers. Liege, Belgium, International Union for the Scientific Study of Population [IUSSP], 1988. :19-41.

Casterline, John B., Lindy Williams and Peter McDonald, 1986, "The age difference between spouses: variations among developing countries", Population Studies 40(3), 353-374.

Czap, P. (1983). »A large family: the peasant's greatest wealth «: Serf households in Mishino, Russia, 1814-1858. In R. Wall, J. Robin, and P. Laslett, (Eds.). Family forms in historic Europe (pp. 105151). Cambridge: Cambridge University Press.

Devas, C.S. (1886). Studies of Family Life: A Contribution to Social Science. London: Burns and Oates.

De Moor, T., and van Zanden, J. L. (2010), 'Girl power: The European ... in the Late Medieval and Early Modern Period', Economic History Review 63: 1-33.

Dovnar-Zapolsky, M. (1909). Očerki semejnogo obyčnogo prava krest'jan Minskoj gub. In M. Dovnar-Zapolsky, Issledovanija i stat'i. T. 1. Ëtnografija i sociologija, obyčnoe pravo, statistika, belorusskaja pis'mennost'. Kiev, 1-60 (originally puiblished in Ètnografičeskoe obozrenie 1897, no. 12).

Efimenko, A. (1892). Dvoriščnoe zemlevladenie v južnoj Rusi. Russkaja Mysl' 5-6, 370-412.

Vera St. Erlich (1966) Family in Transition: A Study of 300 Yugoslav Villages. Princeton.

Bernd J. Fischer (1999) Albanian Highland Tribal Society and Family Structure in the Process of Twentieth Century Transformation. In: East European Quarterly, vol. 33, no. 3, pp.281-301.

Gimbutas, M. (1971). The Slavs. New York: Praeger.

Arjan Gjonça (2001) Communism, Health and Lifestyle: The Paradox of Mortality Transition in Albania, 1950-1990 (Studies in Population and Urban Demography, no. 8). Westport, London. 
Siegfried Gruber (2005) Occupational migration in Albania in the beginning of the 20th century. In: Humanities, Computers and Cultural Heritage: Proceedings of the xvith international conference of the Association for History and Computing. Amsterdam, pp. 136-142.

Siegfried Gruber (2007) Die albanische Volkszählung von 1918 und ihre Bedeutung für die Wissenschaft. In: Helga Kostka, ed., SeinerZeit Redakteur Franz Seiner und seine Zeit (1874 bis 1929). Graz, pp. 253-265.

Siegfried Gruber (2008) Household structures in urban Albania in 1918. In: The History of the Family, vol. 13 , pp. $138-151$.

Siegfried Gruber (2009) Household Formation and Marriage: Different Patterns in Serbia and Albania? In: Antoinette Fauve-Chamoux and Ioan Bolovan, eds., Families in Europe between the $19^{\text {th }}$ and $21^{\text {st }}$ Centuries: From the Traditional Model to the Contemporary PACS (= Romanian Journal of Population Studies Supplement). Cluj-Napoca, pp. 229-247.

Siegfried Gruber (2010) Marriage Patterns in Northern Albania in the Beginning of the $20^{\text {th }}$ Century. In: Marie-Pierre Arrizabalaga, Ioan Bolovan, Marius Eppel, Jan Kok, Mary Louise Nagata, eds., Many Paths to Happiness? Studies in Population and Family History. A Festschrift for Antoinette FauveChamoux. Amsterdam, pp. 404-426.

Siegfried Gruber (2011) The influence of migration on fertility in Albania around 1900. In: Annuario: The Albanian Yearbook of Historical and Anthropological Studies, vol. 1. Tiranë, pp. 122-155.

Siegfried Gruber and Mikołaj Szołtysek (2012) Stem Families, Joint Families, and the European Pattern: What kind of a Reconsideration Do We Need? In: Journal of Family History, vol. 37, no. 1, pp. 105-125.

John Hajnal (1982) Two kinds of preindustrial household formation system. In: Population and Development Review, vol. 8, no. 3, pp. 449-494.

Patricia Kelly Hall, Robert McCaa, Gunnar Thorvaldsen, eds. (2000) Handbook of International Historical Microdata for Population Research. Minneapolis.

Joel M. Halpern and Barbara Kerewsky-Halpern (1972) A Serbian Village in Historical Perspective. New York.

Joel M. Halpern, Karl Kaser, and Richard A. Wagner (1996) Patriarchy in the Balkans: Temporal and Cross-Cultural Approaches. In: The History of the Family, vol. 1, no. 4, pp. 425-442.

Eugene A. Hammel and Peter Laslett (1974) Comparing Household Structure over Time and between Cultures. In: Comparative Studies in Society and History, vol. 16, no. 1, pp. 73-109.

Margaret Hasluck (1954) The Unwritten Law in Albania. Cambridge.

Kanuni i Lekë Dukagjinit (1989) Mbledhur dhe kodifikuar nga Shtjefën K. Gjeçovi. Tirana.

Karl Kaser (1992) Hirten, Kämpfer, Stammeshelden. Ursprünge und Gegenwart des balkanischen Patriarchats. Wien, Köln, Weimar.

Karl Kaser (1993) Ahnenkult und Patriarchalismus auf dem Balkan. In: Historische Anthropologie, vol. 1, pp. 93-122.

Karl Kaser (1996) Introduction: Household and Family Contexts in the Balkans. In: The History of the Family, vol. 1, no. 4, pp. 375-386.

Karl Kaser (2000) Macht und Erbe. Männerherrschaft, Besitz und Familie im östlichen Europa 15001900 (= Zur Kunde Südosteuropas, vol. II/30). Wien, Köln, Weimar.

Kaser, K. (2001). Serfdom in Eastern Europe. In D.I. Kertzer and M. Barbagli (eds.), The history of the European family, Vol. 1, New Haven, pp. 25-62.

Kaser, K. (2002). Power and inheritance: male domination, property and family in Eastern Europe, 1500-1900. History of the Family, 7, 375-395. 
Karl Kaser (2008) Patriarchy after Patriarchy: Gender Relations in Turkey and in the Balkans, 1500 2000 (Studies on South East Europe, vol. 7). Wien, Berlin.

Karl Kaser, Siegfried Gruber, Gentiana Kera, Enriketa Pandelejmoni (2011) 1918 census of Albania, Version 0.1 [SPSS file]. Graz.

Gentiana Kera and Enriketa Pandelejmoni (2008) Marriage in urban Albania (during the first half of the twentieth century). In: Gentiana Kera and Gijs Kessler, eds., Urban Household and Family in Twentieth Century East and South-East Europe. (= The History of the Family, vol. 13, no. 2), pp. 126137.

Kosven, M. O. (1963). Semeinaia obshchina i patronimiia, Izd-vo Akademii Nauk SSSR, Moscow.

Kovalevskii, M. (1885). Obscinnoe zemelelevladenie v Malorossii v XVIII veke. Juridiceskij vestnik, 1, 36-69.

Laslett, P. (1977). Characteristics of the western family considered over time. Journal of Family History 2, 89-115.

Le Play, F. (1871). L'organisation de la famille selon le vrai modele signale par l'histoire de toutes les races et de tous les temps. $3^{\text {rd }}$ edn. Tours: Alfred Mame et fils.

Le Play, F. (1982[1872]). Le Réforme Sociale. In C. Bodard Silver, (Ed.). Frederic Le Play on Family, Work, and Social Change (pp. 259-262). Chicago: Chicago University Press.

Leontovich, F.I.(1896). Krestianskij dvor v litovsko-russkom gosudarstve. Zhurnal Ministerstva Narodnago Prosvescenija Februar, 341- 382.

Lutchitsky, I.V. (1896). Zur Geschichte der Grundeigentumsformen in Kleinrussland. Schmoller's Jahrbuch für Gesetzgebung, Verwaltung und Volkswirtschaft im Deutschen Reich 20, 165-196 (Russian original appeared in 1889).

Łowmiański, H. (1967). Z dziejów Słowian w I tysiącleciu n.e. Warszawa: PWN

Macfarlane, A., 1980. "Demographic structures and cultural regions in Europe", Cambridge Anthropology, 6 (1-2): 1-17.

Madan, T. N. (1962). "The joint family: A terminological clarification," International Journal of Comparative Sociology 3: 7-10.

Melegh, A. (2002). "East/West Exclusions and Discourses on Population in the $20^{\text {th }}$ Century". Working Papers on Population, Family and Welfare, No. 3. Demographic Research Institute, Hungarian Central Statistical Office, Budapest.

Mitterauer, Michael, 1999: A Patriarchal Culture? Functions and Forms of Family in the Balkans, in: Beiträge zur historischen Sozialkunde, secial issue.

Michael Mitterauer and Reinhard Sieder, 1982. The European Family: Patriarchy to Partnership from the Middle Ages to the Present (Blackwell).

Beryl Nicholson (1999) The census of the Austro-Hungarian occupied districts of Albania in spring 1918. A preliminary note on the manuscript (=Centre for Scandinavian Studies Papers, no. 5).

Obrębski, J. (2007). Polesie (ed. by A. Engelking). Warszawa. 
Steven Ruggles (2010) Stem Families and Joint Families in Comparative Historical Perspective. In: Population and Development Review, vol. 36, no. 3, pp. 563-577.

Franz Seiner (1922) Ergebnisse der Volkszählung in Albanien in dem von den österr.-ungar. Truppen 1916-1918 besetzten Gebiete (= Schriften der Balkankommission, Linguistische Abteilung, vol. XIII). Wien, Leipzig.

Daniel Scott Smith (1973). Parental Power and Marriage Patterns: An Analysis of Historical Trends in Hingham, Massachusetts, Journal of Marriage and Family, Vol. 35, No. 3,pp. 419-428.

Holm Sundhaussen (1989) Historische Statistik Serbiens 1834-1914. Mit europäischen Vergleichsdaten (= Südosteuropäische Arbeiten, vol. 87). München.

Mikołaj Szołtysek (2008a) Three kinds of preindustrial household formation system in historical Eastern Europe: A challenge to spatial patterns of the European family. In: The History of the Family, vol. 13, no. 3, pp. 223-257.

Mikołaj Szołtysek (2008b) Rethinking Eastern Europe: household formation patterns in the PolishLithuanian Commonwealth and European family systems. In: Continuity and Change, vol. 23, pp. 389-427.

Szołtysek, M. (2009). Female headship, household position, and gendered well-being in peasant societies: evidence from the territories of the historical Kingdom of Poland (18th century). In Durães, M., Fauve-Chamoux, A., Ferrer, L., Kok, J. (Eds.), The transmission of well-being: gendered marriage strategies and inheritance systems in Europe (17th-20th centuries). Bern [et al.]: Peter Lang, 447-486.

Szołtysek, M. (2012). The genealogy of Eastern European difference: an insider's view. Journal of Comparative Family Studies. Forthcoming.

Mikołaj Szołtysek and Barbara Zuber Goldstein (2009) Historical family systems and the great European divide: the invention of the Slavic East. In: Demográfia, vol. 52, no. 5, pp. 5-47.

Szołtysek, M.; Gruber, S., 2011. All in the bosom of the family? Living arrangements of the aged in two Eastern European joint-family societies. Paper presented at the 36th Annual Meeting of the Social Science History Association (SSHA) "Generation to Generation". Boston Park Plaza Hotel and Towers, Boston, MA, USA, November 2011.

Mikołaj Szołtysek (2011) CEURFAMFORM database, Version 0.1 [SPSS file]. Rostock.

Göran Therborn (2004) Between Sex and Power: Family in the World, 1900-2000 (International Library of Sociology). London, New York.

Warpula, Kirsi, 'Eastern Finnish families on the borderland of historical family forms', History of the Family 7 (2002) 3, 315-326.

Ian Whitaker (1976) Familial roles in the extended patrilineal kingroup in northern Albania. In: John G. Peristiany, Mediterranean Family Structures. Cambridge, pp. 195-203.

Ian Whitaker (1981) A Sack for carrying Things: the Traditional Role of Women in Northern Albanian Society. In: Anthropological Quarterly, vol. 54, no. 3.

Witort, J. (1895). Litewska spólnota rodzinna. Wista 9(1), 1-10.

Worobec, C.D. (1995). Peasant Russia. Family and community in the post-emancipation period. Dekalb 1995.

Young, A. (2000) Women Who Become Men: Albanian Sworn Virgins (Dress, Body, Culture. Oxford, New York. 
8. Maps

Map 1: Spatial distribution of Polish-Lithuanian data

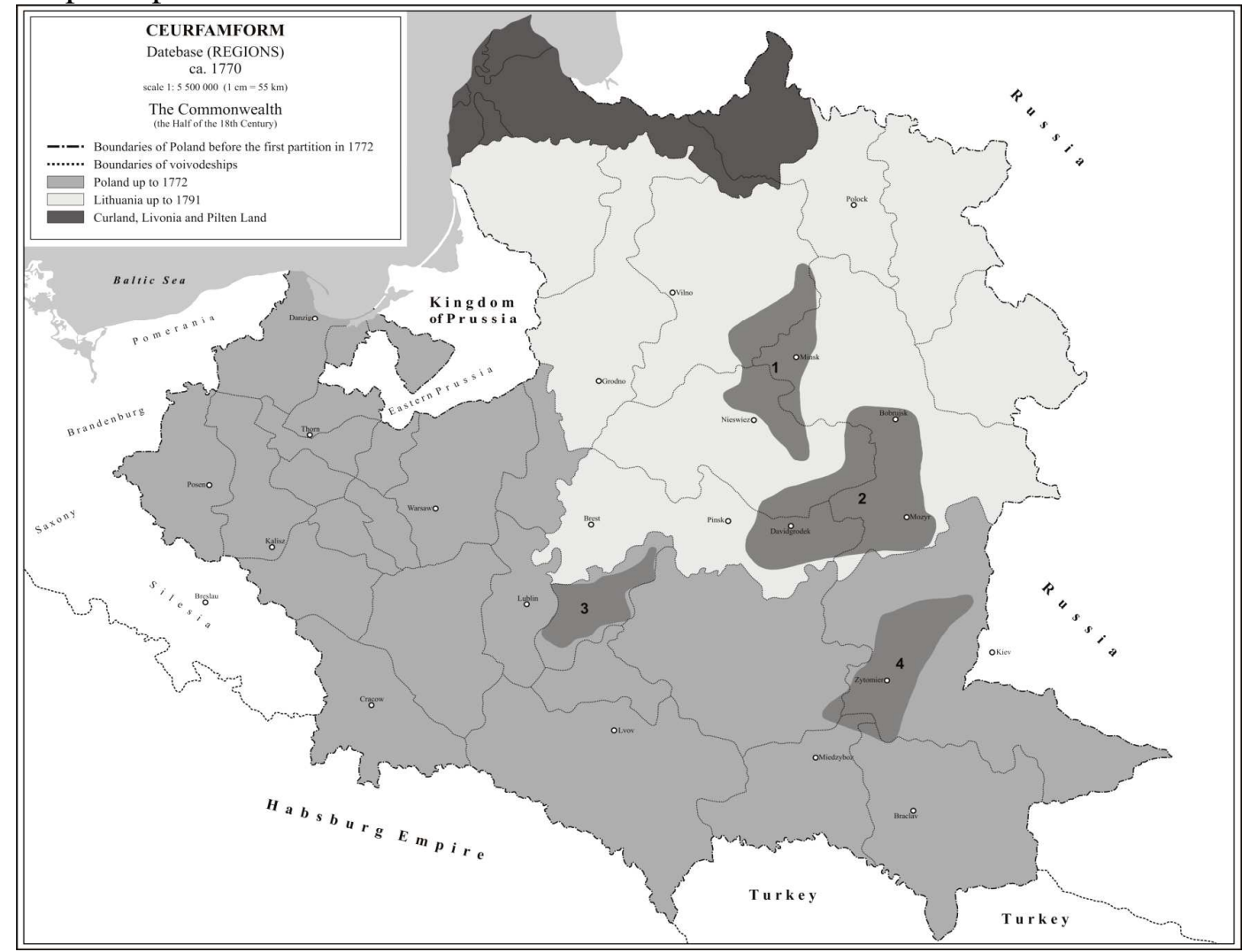

Map design: J. Suproniuk for CEURFAMFORM Database 
Map 2: Regions of the Albanian data

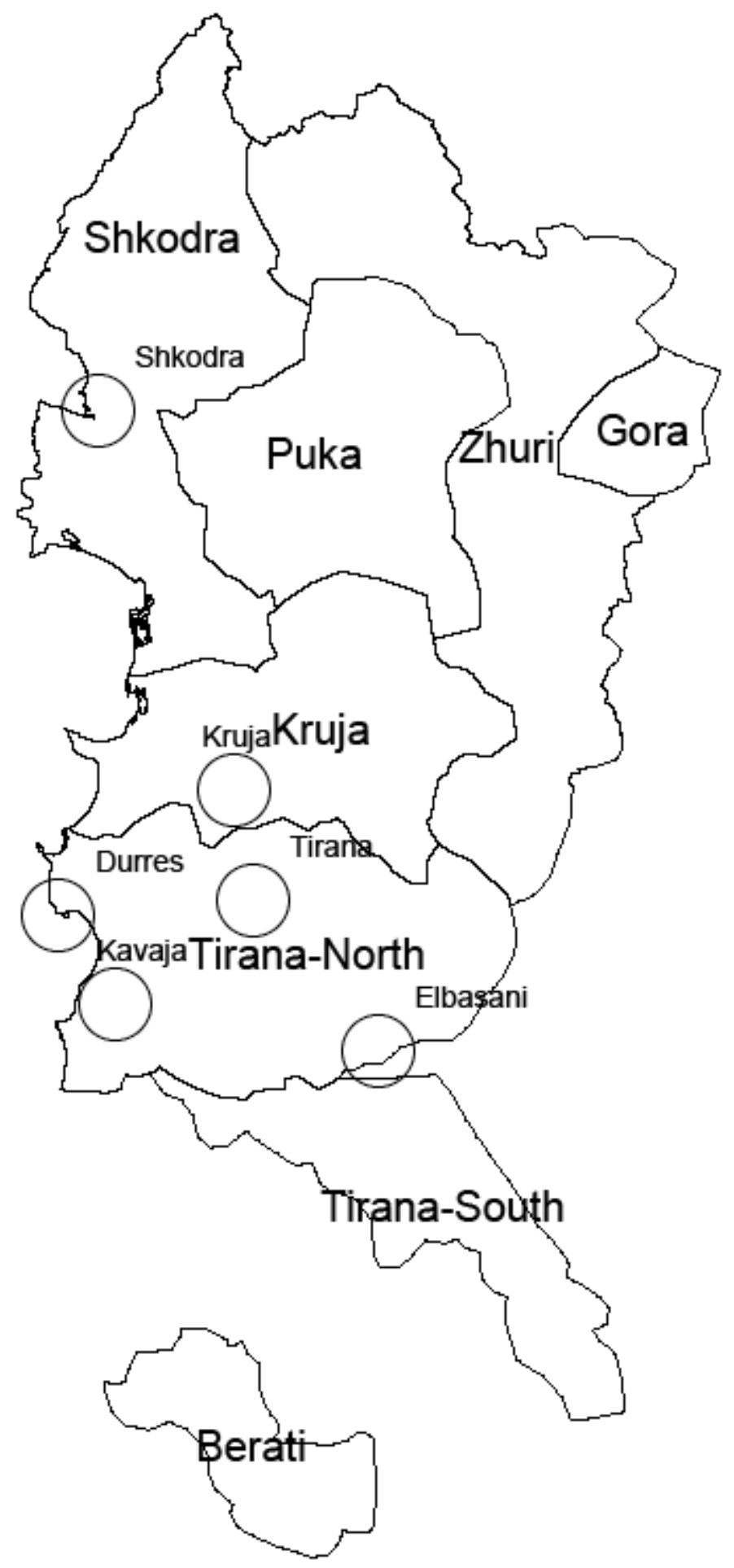


Table 2: Measures of patriarchy

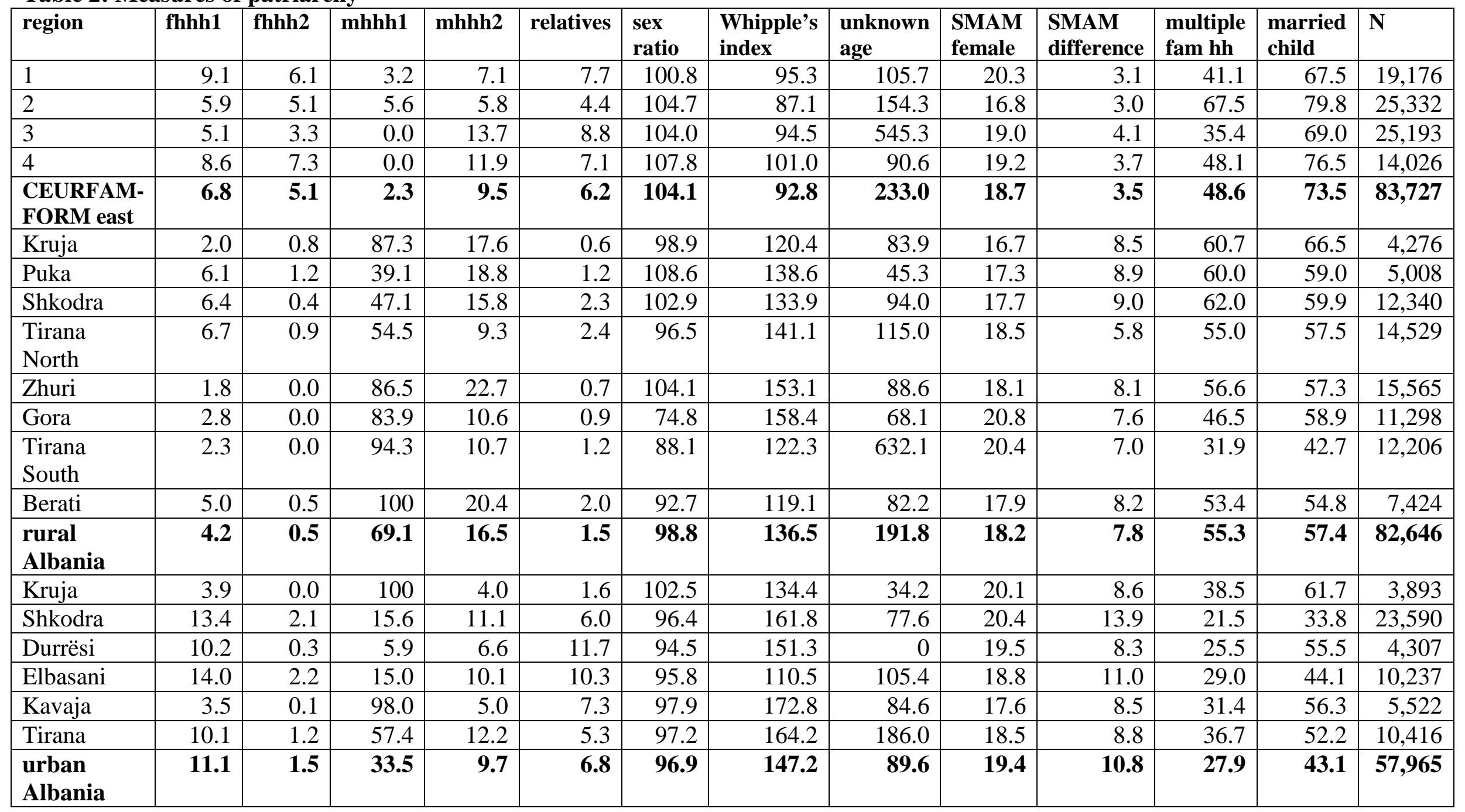


Table 3: Correlation matrix for measures of patriarchy

\begin{tabular}{|c|c|c|c|c|c|c|c|c|c|c|c|c|}
\hline & $\begin{array}{c}\text { percent } \\
\text { female } \\
\text { household } \\
\text { heads }\end{array}$ & $\begin{array}{c}\text { percent } \\
\text { female } \\
\text { household } \\
\text { heads2 }\end{array}$ & $\begin{array}{c}\text { percent male } \\
\text { underage } \\
\text { household } \\
\text { heads }\end{array}$ & $\begin{array}{l}\text { percent of } \\
\text { male } \\
\text { household } \\
\text { heads younger } \\
\text { than oldest } \\
\text { man in } \\
\text { household }\end{array}$ & $\begin{array}{l}\text { percent } \\
\text { wife's } \\
\text { relatives }\end{array}$ & sex ratio & $\begin{array}{l}\text { proportion } \\
\text { of female to } \\
\text { male } \\
\text { Whipple's } \\
\text { index }\end{array}$ & $\begin{array}{l}\text { proportion } \\
\text { of female to } \\
\text { male } \\
\text { persons with } \\
\text { unknown } \\
\text { age }\end{array}$ & $\begin{array}{l}\text { SMAM } \\
\text { women }\end{array}$ & $\begin{array}{l}\text { SMAM } \\
\text { difference }\end{array}$ & $\begin{array}{l}\text { percent } \\
\text { living in } \\
\text { multiple } \\
\text { family } \\
\text { households }\end{array}$ & $\begin{array}{l}\text { percent of } \\
\text { elderly } \\
\text { people } \\
\text { living with } \\
\text { at least one } \\
\text { married } \\
\text { child }\end{array}$ \\
\hline $\begin{array}{l}\text { percent female household } \\
\text { heads }\end{array}$ & 1 & & & & & & & & & & & \\
\hline $\begin{array}{l}\text { percent female household } \\
\text { heads2 }\end{array}$ & 0,381 & 1 & & & & & & & & & & \\
\hline $\begin{array}{l}\text { percent male underage } \\
\text { household heads }\end{array}$ &,$- 702 * *$ &,$- 743 * *$ & 1 & & & & & & & & & \\
\hline $\begin{array}{l}\text { percent of male household } \\
\text { heads younger than oldest man } \\
\text { in household }\end{array}$ & $-0,261$ & $-0,208$ & 0,227 & 1 & & & & & & & & \\
\hline percent wife's relatives &, $694 * *$ & 0,429 &,$- 703 * *$ & $-0,467$ & 1 & & & & & & & \\
\hline sex ratio & 0,118 & 0,452 & $-0,39$ & 0,151 & 0,136 & 1 & & & & & & \\
\hline $\begin{array}{l}\text { proportion of female to male } \\
\text { Whipple's index }\end{array}$ & $-0,038$ &,$- 704 * *$ &, $475^{*}$ & 0,022 & $-0,169$ & $-0,362$ & 1 & & & & & \\
\hline $\begin{array}{l}\text { proportion of female to male } \\
\text { persons with unknown age }\end{array}$ & $-0,244$ & 0,048 & $-0,012$ & 0,018 & 0,007 & $-0,104$ & $-0,335$ & 1 & & & & \\
\hline SMAM women & 0,238 & 0,048 & $-0,1$ & $-0,391$ & 0,191 &,$- 501 *$ & 0,107 & 0,202 & 1 & & & \\
\hline SMAM difference & 0,294 &,$- 617 * *$ & 0,291 & 0,197 & $-0,076$ & $-0,235$ &, $653 * *$ & $-0,299$ & 0,062 & 1 & & \\
\hline $\begin{array}{l}\text { percent living in multiple } \\
\text { family households }\end{array}$ &,$- 474 *$ & 0,091 & 0,15 & 0,466 &,$- 629 * *$ & 0,316 & $-0,293$ & $-0,218$ &,$- 654 * *$ & $-0,375$ & 1 & \\
\hline $\begin{array}{l}\text { percent of elderly people } \\
\text { living with at least one married } \\
\text { child }\end{array}$ & $-0,333$ &, $561 *$ & $-0,251$ & $-0,068$ & $-0,021$ & 0,451 &,$- 574 *$ & $-0,086$ & $-0,376$ &,$- 818 * *$ &, $608 * *$ & 1 \\
\hline
\end{tabular}

**. Correlation is significant at the 0.01 level (2-tailed). *. Correlation is significant at the 0.05 level (2-tailed). 
Table 5: Index of patriarchy

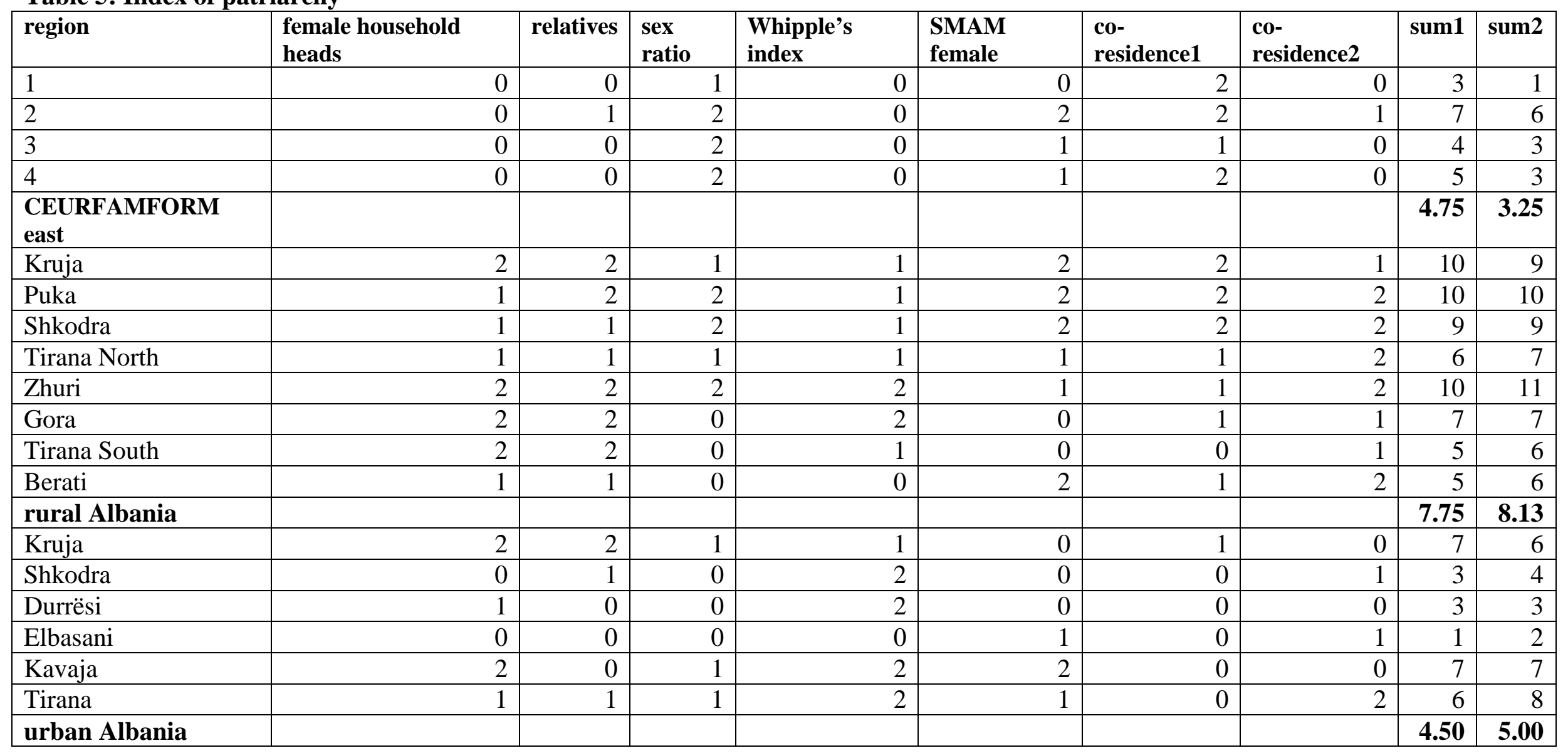

